\title{
Indonesia Companies Face Global Economic Disruption
}

\author{
Alexander Anggriawan \\ University of Surabaya, Surabaya, Indonesia
}

\begin{abstract}
Transforming business and human resources is the best alternative for companies in Indonesia to survive in the midst of global economic uncertainty. Given that changes in business concepts are highly driven and patterned by advances in information technology. Indonesia company have to generate new values in all aspect so that performance can increase and the companies are able to survive.
\end{abstract}

\section{INTRODUCTION}

The global economy condition is unbalanced and Indonesia experienced a decline compared to 2017 because export and imports consistently declined since 2015. In era of economic disruption, business people in Indonesia are required to constantly renew, innovate, permeating with new business capital and adjusting to the industrial revolution 4.0.

The implementation of quality Good Corporate Governance (CGC) enables the creation of added value for stakeholder. CGC is essentially a set of rules that regulate, by implementing CGC companies will get many benefits such as ensuring the establishment of corporate culture. CGC practice and value added creation are expected to meet three dimension, they need to made based on guidelines that officially issues by national government policy committee and expected to meet three dimension, compliance, conformance and performance. Besides employee engagement, companies also need a clear and measurable framework, execution of sustainable strategies and formulating the future according the visions and missions's company. Company that have capability can relate useful values by exploiting opportunities or neutralizing threats in the company external environment. Similarly companies can understand the position of cost and identify ways that can be used yo facilities the implementation of their business level strategies.

\section{METHODS}

This research is growing massively which has an impact on the creation of new employment as reflected in the indicator of employment opportunities. This research use primary and secondary data to understand how business people deal, safe and shape with 
economic disruption. Validation is done gradually to get accurate and in depth result, starts from procurement raw data to analysis process that produce themes and disruption.

\section{RESULT}

The result from 2014 to 2017 was an increased in the population of large and medium industries and manufacturing industry sector was increased. Digital trends create many job opportunities, but most of them have no official legal status and Indonesia's Labor Development Index is low. So, digital trends requires a workforce transformation to learn new competencies to adapt and survive from disruption and industrial revolution 4.0. Each position in organizational structure should have a clear role in the company's strategic achievement, and companies must ready to aligning strategy that conformable with human resouce competencies, culture and organizational structure.

There is a popular adage in the community, "nothing is permanent except change". Its proven with volatility, uncertainty, complexity, and ambiguity (VUCA) that was caused of globalization, digitalization and trade war. Business and human resource transformation are important to face challenges from external and internal factors, as has been implemented by PT. BNI, Tbk. And PT. Hartono Plantation Indonesia (HPI-Argo). Digital transformation from PT. BNI, Tbk is mobile banking, digital loans, mobile remittance, chat banking and QR Codebased payment application, while HPI-Agro creates change on annual plants into seasonal plants, project development into an established organization, investment mode into operational mode, administration into strategic manager, ad-hoc into planning based, traditional organization into modern one, plantations into agricultural industries, offer into demand management and followers into innovators.

Process of transformation is related to innovative ideas and must not violate business ethics and GCG principles such as transparency, accountability, responsibility, independence and fairness in aspects of strategy system, management, organization, information technology, human resources and funding. Many companies are now implementing GCG not only as regulatory obligation, but as part of company's tool and guidelines that can used as operational foundation which makes strategy and management systems works properly and correctly so trust from stakeholder raises. Implementation of sustainable GCG system encourage companies to create new values in the aspects of products, operation and services that improve company performance, and banefully stakeholders that needed in the capital market. GCG 
increase stakeholder's trust and indirectly increase investment by attracting investors in their shares.

The effectiveness of an organizational structure is much influenced by the quality of leadership and the management system implemented to create a superior products and services as expected by the market. Employees sometimes feel that there is no bond with the company (Dessler 2005), that can be a problem and disappoints consumers so employee engagement is needed. Employee engagement able management to improve the conditions of employees' say, stay, and strive through efforts to build high commitment and accommodate aspects of employee satisfaction that turn to implemented into daily operational activities and expected to grow passion, motivation and proactive encouragement.

\section{CONCLUTION}

The conclusion is competitive advanced has become a necessity for every company in Indonesia in facing economic disruption when company wants to survive. Economic disruption has made company leaders face very difficult challenges. The performance target needs to be lower from the top level to the individual so that each employee can move in the same direction. Implementation of CGC can increased company value, market value culture value, and the effectiveness of the audit system. Profit maximization can be abstained if the governance runs well.

\section{REFERENCES}

Tayibnapis, A. Z., Wuryaningsih, L. E., Gora, R. (2019). Companies in Indonesia in the Vortex of Global Economic Disruption. Advances in Social Science, Education and Humanities Research, Vol.308. 